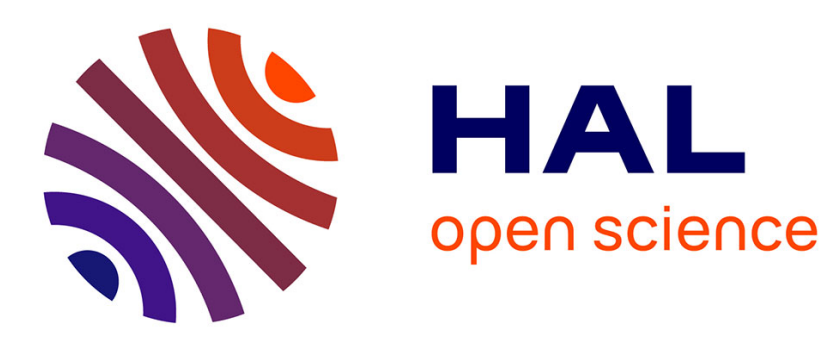

\title{
Right-lateral shear along the Northwest Pacific Margin and the India-Eurasia Collision
}

Laurent Jolivet, Philippe Davy, P. R. Cobbold

\section{To cite this version:}

Laurent Jolivet, Philippe Davy, P. R. Cobbold. Right-lateral shear along the Northwest Pacific Margin and the India-Eurasia Collision. Tectonics, 1990, 9 (6), pp.1409-1419. 10.1029/TC009i006p01409 . insu-00733126

\section{HAL Id: insu-00733126 \\ https://hal-insu.archives-ouvertes.fr/insu-00733126}

Submitted on 18 Sep 2012

HAL is a multi-disciplinary open access archive for the deposit and dissemination of scientific research documents, whether they are published or not. The documents may come from teaching and research institutions in France or abroad, or from public or private research centers.
L'archive ouverte pluridisciplinaire HAL, est destinée au dépôt et à la diffusion de documents scientifiques de niveau recherche, publiés ou non, émanant des établissements d'enseignement et de recherche français ou étrangers, des laboratoires publics ou privés. 
RIGHT-LATERAL SHEAR ALONG

THE NORTHWEST PACIFIC MARGIN AND THE INDIA-EURASIA COLLISION

Laurent Jolivet

Département de Géologie, Ecole normale supérieure, Paris

Philippe Davy and Peter Cobbold

Centre Armoricain d'Etude Structurale des Socles, Université de Rennes I, France

\begin{abstract}
Right-lateral shear along the eastern margin of Asia, from the Eocene to the Present has led to the opening of pullapart basins, intracontinental such as the Bohai basin, or oceanic such as the Japan Sea. We suggest in this paper that this right-lateral shear is a consequence of indentation of Asia by India. As in smallscale analog experiments, we conclude that antithetic wrench faults accommodate the counterclockwise rotation of large domino blocks between two major left-lateral shear zones (Tien Shan-Baikal-Stanovoy for the northern one, and Qin Ling for the southern one). We discuss the compatibility of this mechanism, which involves a rather small amount of extrusion, with the fast eastward expulsion described for southeast Asia. We re-emphasize the role played in the opening of marginal basins by the Pacific subduction as a free boundary to the east.
\end{abstract}

\section{IN'TRODUCTION}

As a result of collision in the Himalayan region, the Asian continent is currently

\section{Copyright 1990}

by the American Geophysical Union.

Paper number 89TC03769. 0278-7407/90/89TC-03769\$10.00 deforming as far as its eastern boundary, behind the peri-Pacific subduction zone. Tapponnier et al. [1982] suggested that opening of the South China Sea is related to extrusion of Indochina along the Red River Fault during the Tertiary (Figure 1). But the South China Sea is only one among several marginal basins which opened during the same time span. Other examples are the Japan Sea, Kuril basin and Shikoku basin. Up to now, no model has convincingly explained the tectonic evolution of the margin as a whole. The Japan Sea and Bohai basin opened in the Cenozoic as large pull-apart basins distributed along rightlateral shear zones parallel to the active margin of Eurasia (Figure 1; Lallemand and Jolivet, 1985; Kimura and Tamaki, 1986; Chen and Nabelek, 1988]. This right-lateral shear is still active today in northern China. It is predicted neither by the classical mechanism of back-arc spreading, nor by the model of Tapponnier et al. [1982] of eastward extrusion. Recently Davy and Cobbold [1988] did analogue experiments of the India-Asia collision which shed a new light on this question (Figures 2 and 3 ). We suggest in this paper that Japan Sea, and, more landward, the Bohai basin, are pullapart basins along right-lateral cross faults which accommodate counterclockwise rotations of large domino-like blocks, due to the India-Asia collision (Figure 4). 


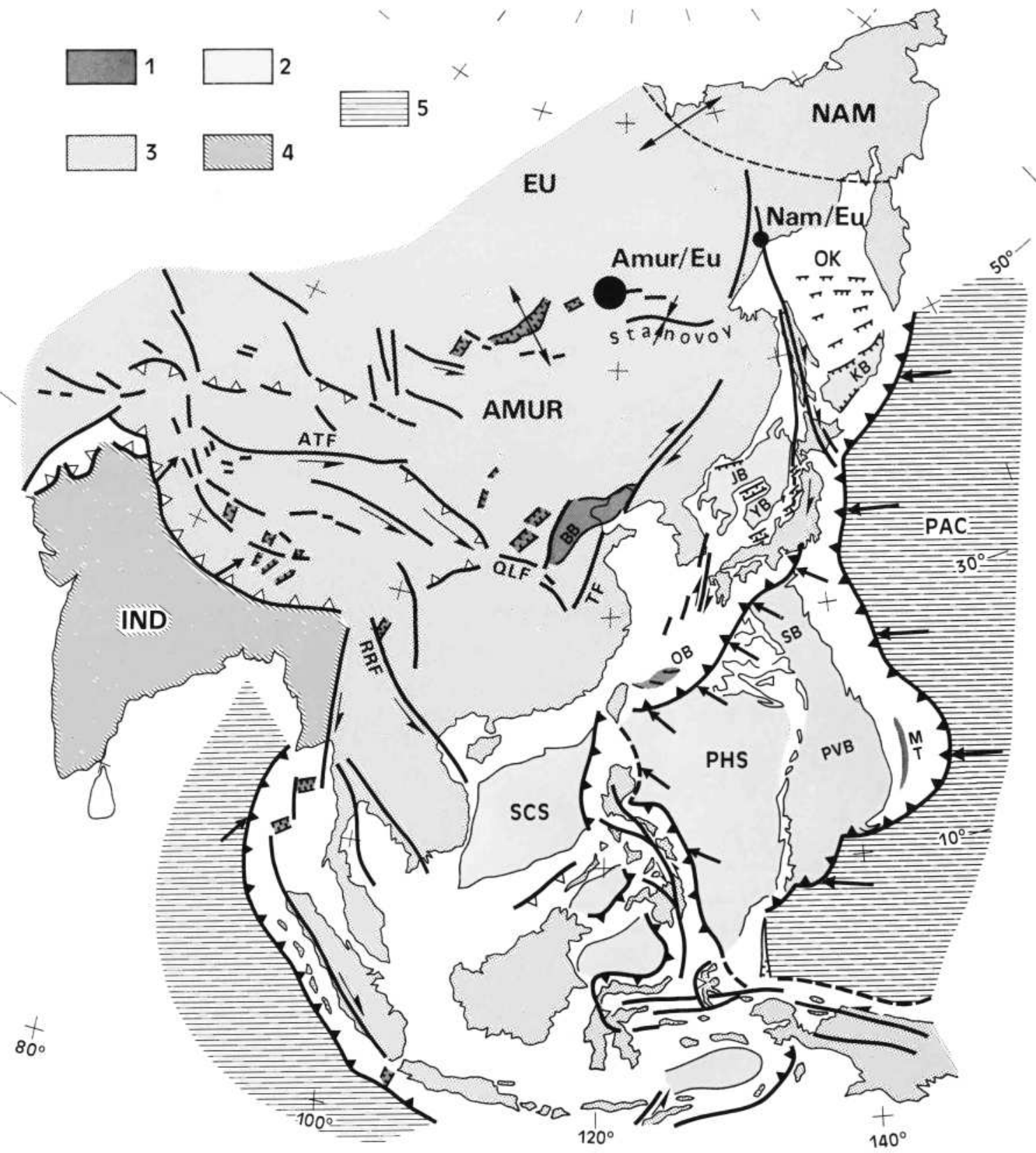

Fig. 1. Tectonic map of eastern Asia and the peri Pacific subduction zones. 1 , Actively opening oceanic basins or intracontinental rifts. 2, Tertiary marginal basins now inactive. 3, Area belonging to Asia. 4, Indian plate. 5, Pacific plate. NAM, North American plate, EU, Eurasian plate, IND, Indian plate, PAC, Pacific plate, OK, Okhotsk plate, PHS, Philippine Sea plate, ATF, Altyn Tagh Fault, QLF, Qin Ling Fault, TF, Tanlu Fault, RRF, Red River Fault, BB, Bohai Basin, JB, Japan Basin, KB, Kuril basin, MT, Mariana trough, OB, Okinawa basin, SB, Shikoku basin, SCS, South China Sea, PVB, Parece Vela basin, YB, Yamato basin. The instantaneous rotation pole Amur/Eu is after Savostin et al. [1983]. Oblique Mercator projection. 

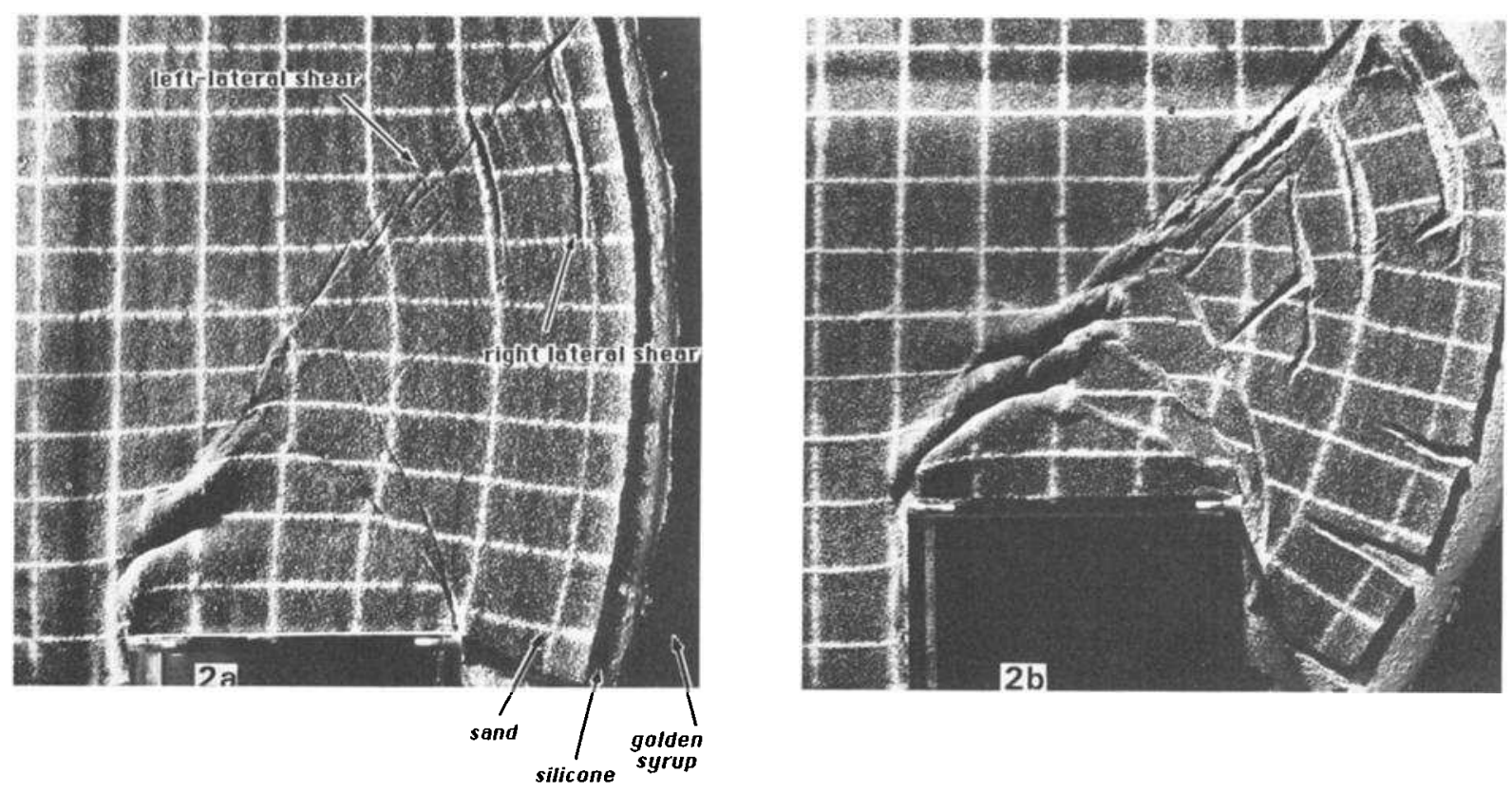

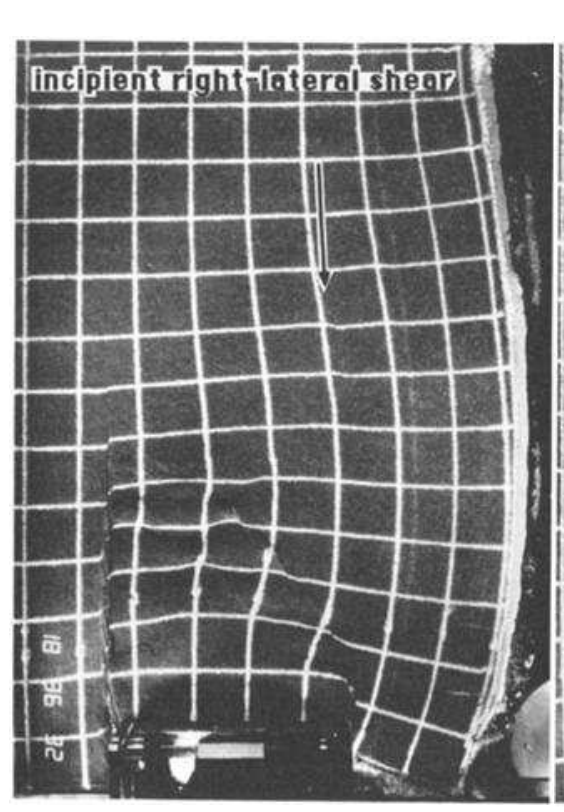

2c

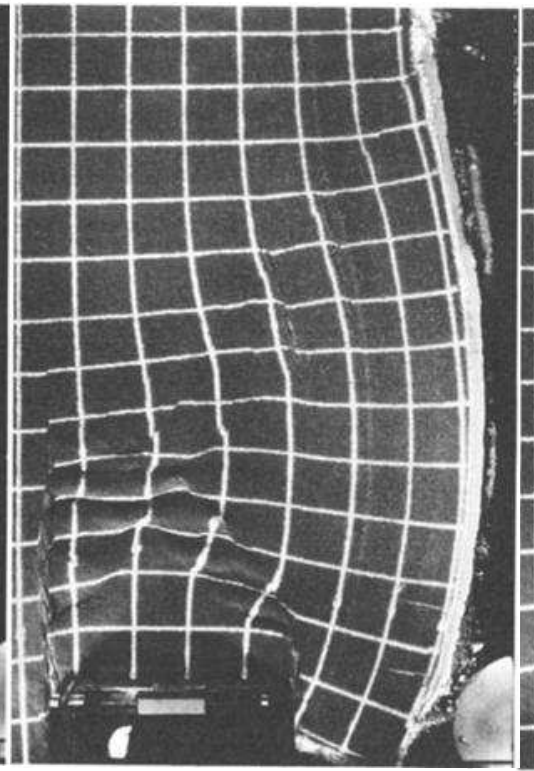

2d

left-lateral shear

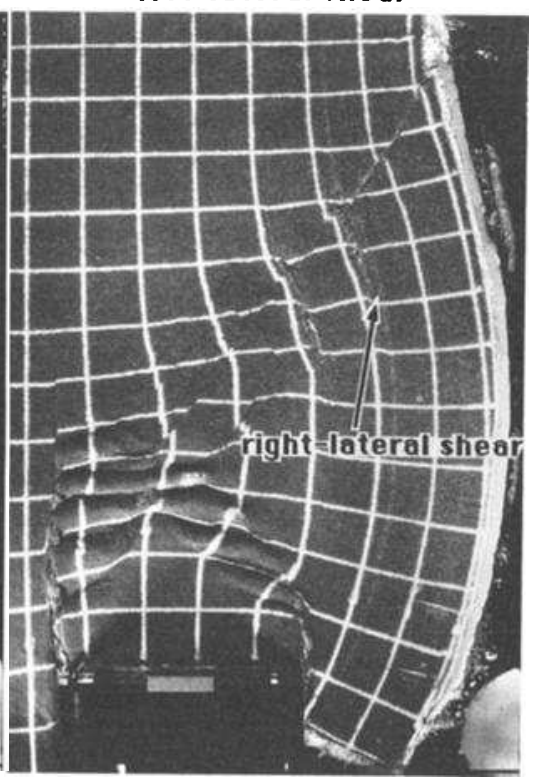

$2 e$

Fig. 2. Photographs of two experinents by Davy and Cobbold [1988]. One is for a two-layer lithosphere (Figures $2 a$ and $2 b$ ), the other for a three-layer lithosphere (Figures 2c, 2d and 2e). For strength profiles see Figure 3. 
NATURE

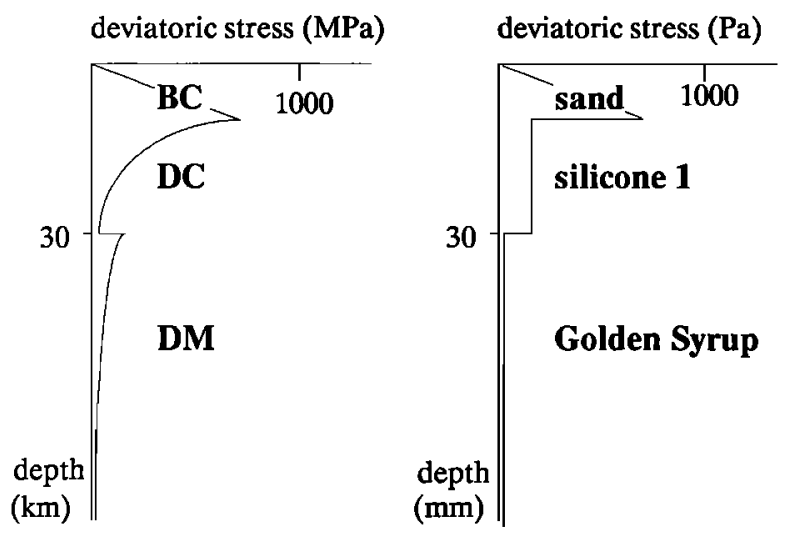

2-LAYER LITHOSPHERE

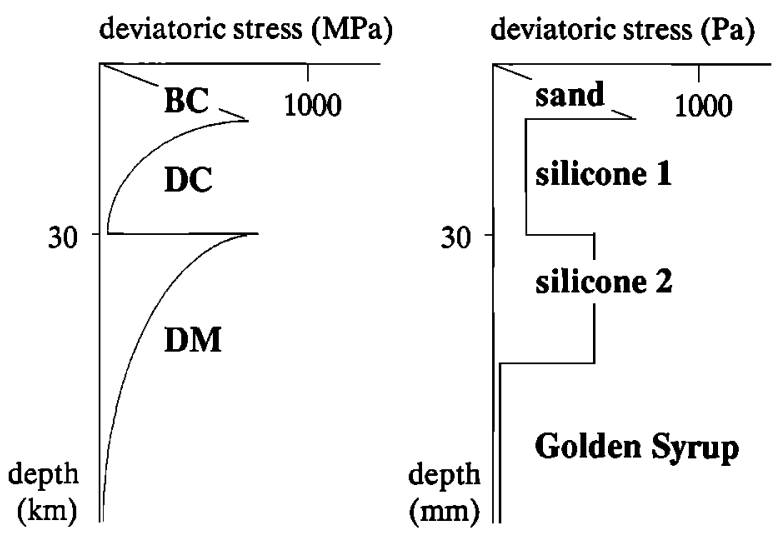

3-LAYER LITHOSPHERE

Fig. 3. Comparison of theoretical rheologic profiles for two and three-layer lithosphere with the profiles used in the experiments. BC, Brittle Crust, DC, Ductile Crust, DM, Ductile Mantle.

It now appears that the opening of many marginal basins is not simply a matter of backward migration of the subducted slab and trench-retreat, as earlier stated [Taylor and Karner, 1983; Uyeda and Kanamori, 1979; Uyeda, 1986; Garfunkel et al., 1986]. Whereas the active Mariana basin or the Miocene Shikoku-Parece Vela basin may be true back-arc basins, many others opened with more complex mechanisms, often involving large transcurrent motions. Recently, Hamburger and Isacks [1988] claimed that the active opening of the northern Fiji and northern Lau Basins is due to left-lateral motion along the Australia-Pacific boundary. The

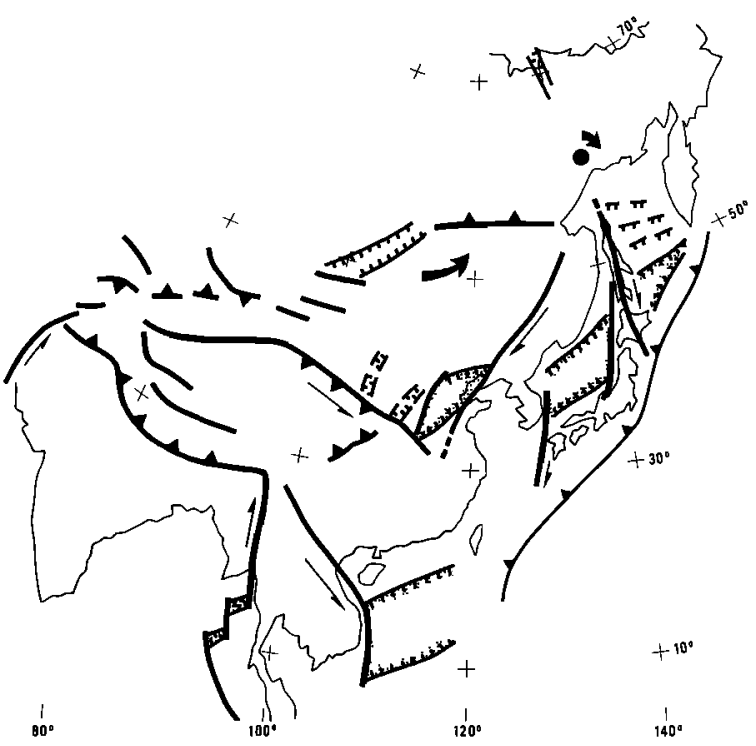

Fig. 4. Simplified model of deformation of Asia (see text for details). Oblique Mercator projection.

deformation is accommodated over a wide area. Kimura and Tamaki [1986] compiled tectonic data for northeast Asia and concluded that the Japan Sea pull-apart opened in response to a northward movement of Eurasia due to collision of India. The movement was accommodated by left-lateral motion along the Baikal rift zone on the west side, compressive tectonics leading to the formation of thrusts along the Stanovoy range and right-lateral motion along the Pacific margin. Jolivet [1986] and Jolivet et al. [1989] explained the rightlateral transpression observed along Sakhalin and Hokkaido during the opening period by the relative motion of the North America and Eurasia plates. But, up to now, no mechanism efficiently explained both the deformation of South-East Asia and the Japan-Okhotsk region. In the following we first shortly review the opening mechanism of the Japan Sea and Bohai basin and then some of the experiments of Davy and Cobbold [1988]. Finally we discuss the tectonics of eastern Asia as a whole.

\section{JAPAN SEA}

The timing of the opening of the Japan Sea, including the rifting period, is deduced from the analysis of the geology of its 
margins. A general agreement has been reached upon a period bracketed between Late Oligocene and the end of Middle Miocene mainly based on the stratigraphy of the onland basins [Tamaki, 1986, 1988; Lallemand and Jolivet, 1985; Otofuji and Matsuda, 1984; Jolivet and Huchon, 1989]. These dates coincide with a peak of volcanic activity in northern Japan known as the Green Tuffs period [Ganzawa, 1987]. According to Ludwig et al. [1975] and Tamaki $[1985,1986,1988]$ oceanic crust underlies three main basins, the Japan (JB) ,Tsushima (TB) and Yamato (YB) basins. The unusually thick crust of the Yamato basin makes this inference partly questionable, a thinned continental crust also being possible. The Japan basin is separated from the smaller Yamato basin by a rifted continental block, the Yamato bank. Although the trend of magnetic anomalies is clearly E-W to ENE-WSW in the Japan basin [Isezaki, 1986; Tamaki, 1988], the magnetic data are not well enough resolved to identify the anomalies themselves. Onland paleomagnetic studies indicate a clockwise rotation of SW Japan and a counterclockwise rotation of NE Japan during the opening [Kawai et al., 1971; Otofuji and Matsuda, 1983; Otofuji et al., 1985a, 1985b; Celaya and McCabe, 1987; Tosha and Hamano, 1988; Moreau et al., 1987]. The motion is that of a double door opening about two nearby rotation poles. Based on different grounds, Faure and Lalevée [1987] argued in favor of a similar model. However this does not take into account the right-lateral strike-slip faults known onland and at sea. The N-S trending Hokkaido Central Belt was a right-lateral transpressional shear zone during the Cenozoic. The end of the strike-slip motion and the beginning of the subsequent $\mathrm{E}-\mathrm{W}$ compression is dated to the end of the Middle Miocene based upon a study of fault sets which gives the stress history within the stratigraphic sequence [Jolivet and Huchon, 1989]. Along the western margin of the Japan Sea, between SW Japan and Korea, a right-lateral shear zone is also known at the same period [Sillitoe, 1977; Lallemand and Jolivet, 1985; Otsuki and Ehiro, 1978]. En échelon normal faults in Early Miocene sediments [Lee and Pouclet, 1988] also favor this right-lateral shear which is confirmed by local paleomagnetic rotations [McCabe et al., 1988]. Early Cenozoic metallogenic belts are offset by 200 $\mathrm{km}$ across this fault zone [Sillitoe, 1977]. Furthermore, structural observations in Kyushu [Murata, 1987; Fabbri et al., 1987], analysis of bathymetric features in the Japan Sea and pre-opening reconstructions [Jolivet et al., Arc deformation and marginal basin opening, Japan Sea as a case study, submitted to Journal of Geophysical Research, 1990] suggest a clockwise rotation of SW Japan by about $20^{\circ}$ and a counterclockwise rotation of $\mathrm{NE}$ Japan by about the same angle, confirming the conclusions reached earlier on the basis of paleomagnetic observations. The model put forward by Jolivet et al. is that of rightlateral shear distributed over the width of the Japan Sea, with rotation of rigid blocks inside the shear zone. In the north of the Hokkaido-Sakhalin strike-slip system, transpression resulted from the southward movement of the Okhotsk plate with respect to Eurasia, whereas in the south the Pacific subduction provided a transtensional environment. Clockwise rotations occurred in the south and counterclockwise rotations in the north.

North of the Japan Sea, the HokkaidoSakhalin right-lateral fault system continues in Sakhalin along more than 2000 km [Kimura et al., 1983; Rozhdestvensky, 1982, 1986]. Focal mechanisms [Savostin et al., 1983] show that this right-lateral shear is still active in the north of Sakhalin, whereas an $\mathrm{E}-\mathrm{W}$ compression prevails in the south and along the eastern margin of the Japan Sea [Fukao and Furumoto, 1975; Nakamura, 1983; Tamaki and Honza, 1984; Lallemand et al., 1985]. This seismic zone was once interpreted as the North AmericaEurasia plate boundary [Chapman and Solomon, 1976], but is now understood as the boundary between the Okhotsk and Amurian blocks [Savostin et al., 1983]. The tectonic history since the Miocene can be described as follows: the whole system, from the north of Sakhalin to the Tsushima Strait between the Korean Peninsula and Japan, was a right-lateral shear zone until the end of the Middle Miocene, after which it changed to a zone of $\mathrm{E}-\mathrm{W}$ compression. The reason for this drastic change is still unclear. The Philippine Sea plate probably 
reached its present position, after its northward drift, by this time [Maruyama and Seno, 1985; Jolivet et al., 1989] and this new situation may have been associated with a change in stress regime, as will be discussed later in the paper.

\section{NORTH CHINA}

The Bohai basin (BB on Figure 1) extends partly offshore in the Yellow Sea and onland as a part of the North China grabens. Since the Eocene, the Bohai basin has a long history of sedimentation [Liu, 1986; Chen and Nabelek, 1988], which cannot be accounted for by simple thermal subsidence [Hellinger et al., 1985]. Chen and Nabelek [1988], analyzing the seismic activity and the subsidence of the Bohai gulf, favor a large right-lateral pull-apart system, active since the beginning of the Cenozoic (see also Cobbold and Davy [1988]). A similar conclusion has been reached by Kumarapeli et al. [1988]. North of the Bohai basin, the northern extension of the Tanlu fault (fig. 1) and its associated Cenozoic basins [Commission for the Geological Map of the World, 1982] could also be right-lateral. Despite the long period of activity of the fault system, the western master fault of the Bohai basin does not offset the Qing Lin belt, which is presently active as a left-lateral fault system [Tapponnier et al., 1986; Peltzer et al., 1985]. The lack of offset is possible if there is relative rotation of the faults. The map traces of the right-lateral faults (Bohai basin and Japan Sea) do not extend to the north of the Stanovoy range, which separates stable Eurasia from the Amurian plate [Savostin et al., 1983]. The latter is bounded to the west by the Baikal rift which is active as an extensional domain [Tapponnier and Molnar, 1979; Zonenshain and Savostin, 1981]. On the basis of compressional seismic activity in the Stanovoy ranges, Savostin et al. [1983] suggested that the Amur/Eurasia instantaneous rotation pole is located at the northwest corner of the Amur plate, which rotates counterclockwise. According to Zonenshain and Savostin [1981] fast extension in the Baikal rift started in the late Neogene. Kimura and Tamaki [1986] suggested that the Baikal system was a leftlateral shear zone in the early Cenozoic contemporaneous with the opening of the
Japan Sea. Tapponnier and Molnar [1979], using seismotectonic data, described the junction between the Baikal rift system and the Stanovoy as a domain of left-lateral pullapart basins. Despite these discrepancies in the interpretation of the tectonics of this area, we suggest that the Japan Sea and Bohai basin opened as pull-apart basins along two N-S right-lateral systems confined between the Baikal-Stanovoy system and the left-lateral Qing-Lin fault. Between the two E-W left-lateral boundary faults, major blocks bounded by N-S right-lateral faults rotated counterclockwise.

\section{SMALL-SCALE MODELLING OF CONTINENTAL INDENTATION}

Davy and Cobbold [1988] recently did some experiments at Rennes with sand and silicone putty to model continental collision (Figure 2). One of the objects of this work was to determine under what conditions indentation produces crustal thickening or instead, eastward extrusion as advocated by Tapponnier et al. [1982, 1986]. We present two experiments chosen from a set of 15 where rheological parameters and boundary conditions vary [Davy and Cobbold, 1988; and work in progress]. Boundary conditions are similar to those used by Peltzer [1987] and Peltzer and Tapponnier [1988] in their experiments, Vilotte et al. [1982, 1985] or Cohen and Morgan [1987] with numerical techniques: a rigid indenter moving northward and an eastern lateral boundary with little constraint (see also England and McKenzie $[1982,1983])$ or Houseman and England [1986] for different boundary conditions). Rheologies were chosen to model a lithosphere made of, at most, three layers: brittle crust (BC), ductile crust (DC) and ductile mantle (DM) (for further details, including scaling, see Davy [1986], Davy and Cobbold [1988]). The sequence of brittle layers (dry sand) and ductile layers (silicone putties of various densities) rested upon a model asthenosphere of high density and low viscosity (glucose syrup). For various rheologies and various degrees of lateral confinement, the resulting deformation pattern varies greatly; but in all experiments a left-lateral shear zone (incipient or well expressed) propagates northeastwards, from the northwestern 
corner of the indenter (a region of stress concentration) as far as the free boundary. We highlight interesting aspects of the fault pattern for two experiments.

\section{Experiment 1}

In the first experiment (Figures $2 \mathrm{a}$ and $2 b)$, a two-layer model crust (brittle/ductile) overlies a weak model mantle with a free boundary to the east (see strength profile, Figure 3). Major structural features appear very early (see Figure $2 \mathrm{a}$, for $5 \mathrm{~cm}$ of northward movement of an indenter $20 \mathrm{~cm}$ wide). A dead triangle formed, as predicted by the theory of plasticity [Tapponnier and Molnar, 1976]. The wrench fault on the left side of the triangle propagated northeastward until it reached the free lateral boundary to the east. With the right side of the dead triangle and the unconstrained lateral boundary it defined a new triangle which was expelled eastward during indentation. A main left-lateral wrench zone (from the western edge of the indenter to the eastern free boundary) was convergent in the SW and divergent in the $\mathrm{NE}$. In the NE, right-lateral rifts accommodated counterclockwise rotation of large domino blocks. The rifts were bounded by faults parallel to the unconstrained margin, that is, they have N-S trends. They may have been initiated as normal faults, but that is not clear from surface views. What is clear is that they subtented very acute angles with the main left-lateral wrench fault, more acute than that between conjugate wrench faults immediately north of the indenter; more acute again than that predicted by Coulomb theory. Aence we suspect that the faults were initiated as normal faults and that the minimum principal stress was perpendicular to the unconstrained margin. In later stages, these faults displayed antithetic (rightlateral) wrench components and then rotated counterclockwise by a domino mechanism, while the rift valley between them continued to develop (Figure 2). At their southern ends, the antithetic rifts terminated against synthetic rifts. These synthetic rifts acquired triangular shapes as the blocks to the north rotated counterclockwise. The synthetic rifts terminated eastwards against antithetic rifts.

\section{Experiment 2}

Here boundary conditions and rheologies were similar to those of experiment 1 except for the presence of a highly-viscous mantle layer beneath the composite crust (Figures $2 \mathrm{c}, 2 \mathrm{~d}$ and $2 \mathrm{e}$ ). The resulting strength profile is more realistic for a cool lithosphere (Figure 3). In comparison with the previous experiment, crustal thickening was a major mechanism of indentation. Thickening occurred in front of the indenter. In particular, en échelon thrusts formed the eastern side of a dead triangle. As in experiment 1 a northeast trending main left-lateral wrench zone formed. In the NE, synthetic faults were mainly wrenches, while antithetic faults exhibited an extensional component. Southern synthetic wrench faults still ended eastwards against antithetic rift-wrench faults.

\section{DISCUSSION}

Cobbold and Davy [1988] suggested that the zone of active deformation of Asia is bounded to the NW by a linear domain between the Tien Shan in the SW and Lake Baikal in the NE. They further showed that all the structures in this domain are compatible with a left-lateral wrenching. The domain is thus comparable with the major wrench zone in the experiments.

We can extend the left-lateral wrench zone as far as the Stanovoy ranges, for the early Cenozoic. The Qing Lin fault can be compared with the subordinate left-lateral faults observed further south in the experiments; the Japan Sea and the Bohai basin, with the right-lateral transtensionnal shear zones which accommodate the rotation of the domino blocks. The present couterclockwise rotation of the North China block described by Savostin et al. [1983] or the left-lateral motion suggested by Kimura and Tamaki [1986] and Tapponnier and Molnar [1979] for the Baikal and Stanovoy ranges are compatible with this system.

Major differences however exist between the experiments and the actual tectonic pattern of the northern part of Asia. A major discrepancy is the transpressional tectonic regime through Sakhalin and Hokkaido, instead of the transtensional one in the experiments. This is perhaps due to the relative motion of Okhotsk and Amur. 
The eastern boundary of Asia is not free, north of the Japan-Kuril trench corner. This contrasts with the assumption of little confinement made in the experiments.

A second possible difference is the amount of extrusion. In nature the deformation may be more localized and the extrusion greater in the southern regions, if we follow Tapponnier et al. [1986]. Recent observations along the Red River fault by Tapponnier et al. [1990] confirm that this is a Miocene left-lateral fault with large amount of slip.

Apparently the plasticine experiments [Tapponnier et al., 1982] give a better rendering of the extrusion mechanism in the south, whereas these new experiments [Davy and Cobbold, 1988] better model the tectonic pattern far from the indenter.

However the left-lateral Red River fault could also be a subordinate and conjugate to a major right-lateral wrench zone along the eastern edge of the indenter [Cobbold and Davy, 1988]. If so, it would accommodate dextral rotation of Indochina about a nearby pole and the extrusion would be less important than postulated by Tapponnier et al. [1986].

Despite these discrepancies, which can partly be explained, a consistent scheme remains for the north: the Japan Sea and Bohai basin opened as right-lateral pullaparts along cross faults which accommodated left-lateral rotation of domino blocks north of the Qing Lin fault (Figure 4). Associated with a more important extrusion in the south than shown by the silicone-sand experiments, the model described here may explain why the South China and Japan Sea opened contemporaneously (or perhaps slightly later for the Japan Sea). The model also may account for the fact that the Bohai fault system does not offset the Qing Lin fault, provided the two faults rotate with respect to one another.

We believe that opening was allowed by the lack of constraint along the Pacific subduction zone and that intracontinental deformation processes only imposed the strike-slip component of the opening. The Shikoku and Parece Vela basins which opened in the same period [Chamot-Rooke et al., 1987; Mrozowski and Hayes, 1979] are simple back-arc basins not linked with intracontinental deformation. An overall tensional stress field was probably active along the peri-Pacific subduction zone after the absolute motion change of the Pacific plate at $45 \mathrm{Ma}$. Rifting began soon afterwards inside the young Palau-KyushuBonin arc. The opening of the Japan Sea stopped in the Late to Middle Miocene when the Pacific-Philippine-Eurasia triple junction reached its present position after the northward drift of the Philippine Sea plate during the Oligocene and the Early and Middle Miocene [Jolivet et al., 1989]. The length of the free boundary on the eastern side has thus been progressively reduced to the present-day length of the Japan trench (between the Kuril and Bonin trenches) and one can assume that the trench retreat forces were no longer sufficient to promote opening in the back-arc region. This simple statement, together with the boundary conditions which seem necessary in all the experiments (twodimensional or three-dimensional) and numerical models to simulate the deformation actually observed, imply that the free boundary along the subduction zone is the most important parameter controlling the opening of marginal basins. One may further assume that, without the internal deformation of Asia due to the collision with India, marginal basins would have opened in a symmetric way, as do the active Okinawa or Mariana basins [McCabe and Uyeda, 1982; Stern et al., 1984; Letouzey and Kimura, 1985; Sibuet et al., 1987].

\section{REFERENCES}

Celaya, M., and R. Mac Cabe, Kinematic model for the opening of the Sea of Japan and the bending of the Japanese islands, Geology, 15, 53-57, 1987.

Chamot-Rooke, N., V. Renard, and X. Le Pichon, Magnetic anomalies in the Shikoku Basin, a new interpretation, Earth Planet. Sci. Lett., 83, 214-223, 1987.

Chapman M.C., and S.C. Solomon, North American-Eurasian plate boundary in northeast Asia, J. Geophys. Res., 81, 921930, 1976.

Chen, W.P., and J. Nabelek. Seismogenic strike-slip faulting and the development 
of the North China basin, Tectonics, 7 , 975-989, 1988.

Cobbold, P.R., and Ph. Davy, Indentation tectonics in nature and experiment. 2. Central Asia, Bull. Geol. Inst. Univ. Uppsala, 14, 143-162, 1988.

Cohen, J.C., and R.C. Morgan, Intraplate deformation due to continental collision: a numerical study of deformation in a thin viscous sheet, Tectonophysics, 123, 247$260,1987$.

Commission for the Geological Map of the World, Tectonic map of South and East Asia, scale 1:5, 000 000, Hyderabad, India, 1982.

Davy, $\mathrm{Ph} .$, Modélisation thermo-mécanique de la collision continentale, Mem. Doc. Centre Arm. Struct. Socles, Rennes, 8 , 233p, 1986.

Davy, Ph., and P.R. Cobbold, Indentation tectonics in nature and experiments. 1 . Experiments scaled for gravity, Bull. Geol. Inst. Univ. Uppsala, 14, 129-141, 1988.

England, P.C., and D.P. McKenzie, A thin viscous sheet model for continental deformation, Geophys. J. R. Astron. Soc., 70, 295-321, 1982.

England, P.C., and D.P. McKenzie. A thin viscous sheet model for continental deformation, Geophys. J. R. Astron. Soc., 73, 523-592, 1983. (Correction to A thin viscous sheet model for continental deformation, Geophys. J. R. Astron. Soc., 70, 295-321, 1982).

Fabbri, O., J. Charvet, and M. Faure, Sur la déformation associée à la rotation de Kyushu (Japon SW) au Miocène Moyen, C. R. Acad .Sci., Ser. 2, 304, 1207-1212, 1987.

Faure, M., and F. Lalevée, Bent structural trends of Japan: flexural slip folding related to the Neogene opening of the sea of Japan, Geology, 15, 49-52, 1987.

Fukao, Y., and M. Furumoto, Mechanisms of large earthquakes along the eastern margin of the Japan Sea, Tectonophysics, 25, 247-266, 1975.

Ganzawa, Y, Fission track age of volcanic rocks from Cretaceous to Tertiary in the inner belt of northeast Japan -Okushiri island, Oga peninsula and Asahi mountains, J. Geol. Soc. Jpn., 93, 387-401, 1987.
Garfunkel, Z., C.A. Anderson, and G. Schubert, Mantle circulation and the lateral migration of subducted slab, $J$. Geophys. Res., 91, 7205-7223, 1986.

Hamburger, M.W., and B.L. Isacks, Diffuse back-arc deformation in the southwestern Pacific, Nature, 332, 599-604, 1988.

Hellinger, S.J., K.M. Shedlock, J.G. Sclater, and $\mathrm{H}$. Ye, The Cenozoic evolution of the North China Basin, Tectonics, 4, 343-358, 1985.

Houseman, G. and P. England, Finite strain calculations of continental deformation, 1, Methods and general results for convergent zones, J. Geophys. Res., 91, 3651-3663, 1986.

Isezaki, N., A magnetic anomaly map of the Japan Sea, J. Geomagn. Geoelectr., 38, 403-410, 1986.

Jolivet, L., America-Eurasia plate boundary in eastern Asia and the opening of marginal basins, Earth Planet. Sci. Lett., 81, 282-288, 1986.

Jolivet, L., and Ph. Huchon, Crustal scale strike-slip deformation in Hokkaido, Northeast Japan, J. Struct. Geol., 11, 509$522,1989$.

Jolivet, L., Ph. Huchon, and C. Rangin, Tectonic setting of western Pacific marginal basins, Tectonophysics, 160, 2348, 1989.

Kawai, N., T. Nakajima, and T. Hirooka, The evolution of the island arc of Japan and the formation of granites in the circum Pacific belt, J. Geomagn. Geoelectr., 23, 267-293, 1971.

Kimura, G., S. Miyashita, and S. Miyasaka, Collision tectonics in Hokkaido and Sakhalin, in Accretion Tectonics in the Circum Pacific Regions, edited by $\mathrm{M}$. Hashimoto and S. Uyeda, pp.117-128., Terrapub, Tokyo, 1983.

Kimura, G., and K. Tamaki, Collision, rotation and back arc spreading: the case of the Okhotsk and Japan seas, Tectonics, 5, 389-401, 1986.

Kumarapeli, S., H. Dong, H. Wang, and Q. Qi, Tanlu fracture zone, east China: An element of an ancient transform belt? (Abstract), 4th International Circum Pacific Terrane Conference, edited by D.G. Howell and Y Shi, 1988, p. 50, Nanjing, September, 1988.

Lallemand, S., and L. Jolivet, Japan Sea, a 
pull apart basin, Earth Planet. Sci. Lett., 76, 375-389, 1985.

Lallemand, S., H. Okada, K. Otsuka, and L. Labeyrie, Tectonique en compression sur la marge Est de la Mer du Japon: Mise en évidence de chevauchements à vergence orientale, C. R. Acad. Sci. , Ser. 2, 301, 201-206, 1985.

Lee, J.S., and A. Pouclet, Le volcanisme néogène de Pohang (SE Corée), nouvelles contraintes géochronologiques pour l'ouverture de la mer du Japon, $C$. $R$. Acad. Sci. Paris, Ser. 2, 307, 1405-1411, 1988.

Letouzey, J., and M. Kimura. Okinawa trough genesis: structure and evolution of a back arc basin developed in a continent, Mar. Pet. Geol., 2, 111-130, 1985.

Liu, H, Geodynamic scenario and structural styles of mesozoic and cenozoic basins in China, Bull. Am. Assoc. Pet. Geol., 70, 377-395, 1986.

Ludwig, W.J., S. Murauchi, and R.E. Houtz, Sediments and structure of the Japan Sea, Geol. Soc. Am. Bull., 86, 651664, 1975.

Maruyama, S., and T. Seno, Mutual plate motions and orogenic movements in the Japanese islands, Kagaku, Tokyo, 55, 3241, 1985.

McCabe, R., K.D. Min, J. Han, H.C. Han, and $\mathrm{D}$. Lee, Block rotations in southeast and east Asia, inTectonics of eastern Asia and western Pacific continental margin, DELP Pub. 22, pp. 35-36, Dynamic and Evolution of the Lithosphere Project,Tokyo, 1988.

McCabe, R., and S. Uyeda, Hypothetical model for the bending of the Mariana arc, in The tectonic and geologic evolution of southeast Asian Seas and Islands, Geophys. Monogr. Ser., vol. 27, edited by D.E. Hayes, pp. 281-293, AGU, Washington, D.C., 1982.

Moreau, M.G., Courtillot, V., and, J. Besse, Evidence for a Miocene widespread remagnetization in northern Japan, Earth Planet. Sci. Lett., 84, 321-338, 1987.

Mrozowski, C.L., and D.E. Hayes, The evolution of the Parece Vela basin, eastern Philippine sea, Earth Planet. Sci. Lett., 46, 49-67, 1979.

Murata, A, Conical folds in the Hitoyoshi bending, South Kyushu formed by the clockwise rotation of the Southwest Japan arc, J. Geol. Soc. Jpn., 93, 91-105, 1987.

Nakamura, K, Possible nascent trench along the eastern Japan Sea as the convergent boundary between Eurasia and North American plates, (in Japanese with English abstract), Bull. Earthquake Res. Inst., Univ. Tokyo, 58, 721-732, 1983.

Otofuji, Y., and T. Matsuda, Paleomagnetic evidence for the clockwise rotation of southwest Japan, Earth Planet. Sci. Lett., 62, 349-359, 1983.

Otofuji, Y., and T. Matsuda, Timing of rotationnal motion of southwest Japan inferred from paleomagnetism, Earth Planet. Sci. Lett., 70, 373-382, 1984.

Otofuji, Y., A. Hayashida, and M. Torii, When did the Japan Sea open?

Paleomagnetic evidence from southwest Japan, in The Formation of Active Ocean Margins, edited by N. Nasu, K.

Kobayashi, S. Uyeda, I. Kushiro, and H. Kagami, pp. 551-566, Terrapub, Tokyo, 1985a.

Otofuji Y. , T. Matsuda, and S. Nohda, Paleomagnetic evidence for the Miocene counter clockwise rotation of northeast Japan - rifting process of the Japan arc, Earth Planet. Sci. Lett., 75, 265-277, 1985 b.

Otsuki K., and M. Ehiro, Major strike-slip faults and their bearing on the spreading of the Japan Sea, J. Phys. Earth, 26, suppl., 537-555, 1978.

Peltzer, G., Contribution à l'étude de la collision Inde-Asie. 1) Approche expérimentale, équilibbre entre épaississement crustal et extrusion latérale. 2) Estimation des déplacements quaternaires sur le bord nord du Tibet, Thesis, 330 pp., Université Paris 7, Paris, September, 1987.

Peltzer, G., P. Tapponnier, Z.T. Zheng, and Z.Q. Xu, Neogene and Quaternary faulting in and along the Qin Ling Shan, Nature, 317, 500-505, 1985.

Peltzer, G., and P. Tapponnier, Formation and evolution of strike-slip faults, rifts and basins during the India-Asia collision: an experimental approach, $J$. Geophys. Res., 93, 15085-15118, 1988.

Rozhdestvenskiy, V.S., The role of wrench faults in the structure of Sakhalin, Geotectonics, 16, 323-332, 1982. 
Jolivet et al.: Pacific Margin Shear and India-Eurasia Collision

Rozhdestvenskiy, V.S., Evolution of the Sakhalin fold system, Tectonophysics, 127, 331-339, 1986.

Savostin, L., L. Zonenshain, and B. Baranov, Geology and plate tectonics of the Sea of Okhotsk, in Geodynamics of the Western Pacific and Indonesian region,Geodynam. ser., vol. 11, edited by W.C.T. Hilde and S. Uyeda, pp. 343-354, AGU, Washigton, D.C., 1983.

Sibuet, J.C., J. Letouzey, F. Barbier, J. Charvet, J.P. Foucher, T.W.C. Hilde, M. Kimura, C. Lin-Yun, B. Marsset, C. Muller, and J.F. Stephan, Back-arc extension in the Okinawa trough, $J$. Geophys. Res., 92, 14041-14063, 1987.

Sillitoe, R.H, Metallogeny of an Andean type continental margin in South Korea, implications for opening of the Japan Sea, in Island Arcs, Deep Sea Trenches and Back-Arc Basins, Maurice Ewing Ser. , vol. 1, edited by M. Talwani and W.C. Pitman III, pp. 303-310, AGU, Washington, D.C., 1977.

Stern, R.J., N.C. Smoot, and M. Rubin, Unzipping of the volcano arc, Japan, Tectonophysics, 102, 153-174, 1984.

Tamaki, K, Two modes of back arc spreading, Geology, 13, 475-478, 1985.

Tamaki, K, Age estimation of the Japan Sea on the basis of stratigraphy, basement depth and heat flow data, J. Geomagn. Geoelectr., 38, 427-446, 1986.

Tamaki, K, Geological structure of the Japan Sea and its tectonic implications, Bull. Geol. Surv. Jpn., 39, 269-365, 1988.

Tamaki, K., and E. Honza, Incipient subduction and obduction along the eastern margin of the Japan Sea, Tectonophysics, 119, 381-406, 1984.

Tapponnier, P., and P. Molnar, Slip line field theory and large scale continental tectonics, Nature, 264, 319-324, 1976.

Tapponnier, P., and P. Molnar, Active faulting and Cenozoic tectonics of the Tien Shan, Mongolia, and Baikal regions, J. Geophys. Res., 84, 3425-3459, 1979.

Tapponnier, P., G. Peltzer, A.Y. Le Dain, R. Armijo, and P. Cobbold, Propagating extrusion tectonics in Asia: new insights from simple experiments with plasticine, Geology, 10, 611-616, 1982.

Tapponnier, P., G. Peltzer, and R. Armijo, On the mechanics of the collision between India and Asia, Spec. Publ.Geol. Soc. London, 19, 115-157, 1986.

Tapponnier, P., R. Lacassin, P.H. Leloup, U. Schärer, Z. Dalai, W. Haiwei, L.

Xiaohan, J. Shaocheng, Z. Lianshang, and Z. Jiayou, The Ailao Shan/Red River metamorphic belt: Tertiary left-lateral shear between Indochina and South China, Nature, 343, 431-437, 1990.

Taylor, B., and Karner, G.D, On the evolution of marginal basins, Rev. Geophys., 21, 1727-1741, 1983.

Tosha, T., and Y. Hamano, Paleomagnetism of Tertiary rocks from the Oga peninsula and the rotation of northeast Japan, Tectonics, 7, 653-662, 1988.

Uyeda, S., Facts, ideas and open problems on trench-arc-backarc systems, inThe Origin of Arcs, edited by F.C. Wezel, Elsevier, New York, pp.435-460, 1986.

Uyeda S., and H. Kanamori, Backarc opening and the mode of subduction, $J$. Geophys. Res., 84, 1049-1061, 1979.

Vilotte, J.P., M. Daignières, and R. Madariaga, Numerical modelling of intraplate deformation: Simple mechanical models of continental collision, J. Geophys. Res., 87, 1070910728, 1982.

Vilotte, J.P., R. Madariaga, M. Daignières, and $\mathrm{O}$. Zinkiewicz, Numerical study of continental collision, influence of buoyancy forces and an initial stiff inclusion, Geophys. J. R. Astron. Soc., 84, 279-310, 1985.

Zonenshain, L.P., and L.A. Savostin, Geodynamics of the Baikal rift zone and plate tectonics of Asia, Tectonophysics, $76,1-45,1981$.

P. Cobbold and Ph. Davy, Centre Armoricain d'Etude Structurale des Socles (CNRS), Université de Rennes I, Avenue du Général Leclerc, 35042 Rennes Cedex, France.

L. Jolivet, Département de Géologie, Ecole Normale Supérieure, 24 rue Lhomond, 75231 Paris cedex 05, France.

(Received June 8, 1989; revised December 6, 1989; accepted December 20, 1989.) 